\title{
Liberdade de empresa, identidade cooperativa e responsabilidade social do cooperativismo: a redenção do socialis et adminicula hominum
}

\author{
Freedom of business, cooperative identity \\ and social responsibility of cooperativism: the redemption \\ of socialis et adminicula hominum
}

José Eduardo de Miranda'

Andréa Corrêa Lima²

UniMB

Sumário: I. Introdução; II. Ponderação preliminar: da livre iniciativa à liberdade para o exercício da atividade empresarial; III. A responsabilidade social e a redenção do socialis et adminicula hominum; IV. Ponto determinante: o que é a identidade cooperativa? V. O emprego do princípio da educação e informação, como mote de difusão dos valores cooperativos: uma experiência prática alicerçada sobre a axiologia da cooperação, com o propósito de fortalecer a construção da cidadania e defesa do meio ambiente; VI. A título de últimas palavras: a responsabilidade social como causa e efeito do Cooperativismo. Referências.

Resumo: De acordo com a Constituição brasileira, a ordem econômica preconiza a liberdade de empresa, sempre e quando exercida com observância dos princípios que enaltecem a condição do homem e a qualidade do meio. Neste sentido, a responsabilidade social determina que todas as estratégias de negócio sejam pensadas e desenvolvidas otimizando o envolvimento das organizações com as questões que revelem-se prioritárias à realização das pessoas, direta ou indiretamente integradas ao negócio, e à melhoria das condições do entorno. Dentro desta ótica, a identidade cooperativa promulgada pela Aliança Cooperativa Internacional realça a integração do conceito de cooperativa aos valores e princípios que assentam que o homem é o início e o fim do Coopera-

1 Doutor em Direito cum laude academica; Mestre em Direito; Reitor do UniMB; Advogado Parecerista; Consultor Jurídico e Educacional; Fundador de Miranda \& Corrêa Lima. E-mail: jemiranda@mirandacorrealima.com

2 Mestra em Direito; Professora e Supervisora Acadêmica do UniMB; Advogada fundadora de Miranda \& Corrêa Lima. E-mail: aclima@mirandacorrealima.com 
tivismo. Atuar em consonância com o bem social, e o bem do indivíduo, porquanto vértice representativo da responsabilidade social é, na essência, a causa e o efeito do próprio Cooperativismo. Este propósito, confirmou-se possível fora do ambiente das Cooperativas, através de desenvolvimento de um experimento prático, conduzido por um Grupo de Pesquisa implantado no Centro Universitário UNICNEC, na cidade de Osório, no Estado do Rio Grande do Sul.

Palavras-chave: Liberdade de empresa; Cooperativismo; Sociedade cooperativa; Responsabilidade social; Experiência prática de emprego dos valores cooperatios, para a construção da cidadania.

\begin{abstract}
According to the Brazilian Constitution, the economic order advocates freedom of enterprise, provided that it is exercised in compliance with the principles that enhance the condition of man and the quality of the environment. In this sense, social responsibility determines that all business strategies are thought and developed, optimizing the involvement of organizations with issues that prove to be priority to the realization of people, directly or indirectly integrated into the business, and to the improvement of the surrounding conditions. Within this perspective, the cooperative identity promulgated by the International Cooperative Alliance emphasizes the integration of the concept of cooperative with the values and principles that establish that man is the beginning and the end of Cooperativism. Acting in line with the social good, and the good of the individual, since the vertex representing social responsibility is, in essence, the cause and effect of Cooperativism itself. This purpose was confirmed possible outside the Cooperatives environment, through the development of a practical experiment, conducted by a Research Group located at the UNICNEC University Center, in the city of Osório, in the State of Rio Grande do Sul.
\end{abstract}

Keywords: Freedom of enterprise; Cooperativism; Cooperative society; Social responsibility; Practical experience of using cooperative values to build citizenship. 
Los egoístas y los individualistas son la quinta columna de la cooperación.

José Maria Arizmendiarrieta ${ }^{3}$

\section{Introdução}

No âmbito do Direito brasileiro, a Constituição Federal, ademais de instituir a ordem econômica como um «conjunto de normas que define, institucionalmente, um determinado modo de produção econômica» ${ }^{4}$, prescreve as maneiras através das quais as relações econômicas serão desenvolvidas.

Sob esta ótica, os imperativos constitucionais estabelecem, pelo artigo 170, da Carta Política, que a ordem econômica é «fundada na valorização do trabalho humano e na livre iniciativa, tem por fim assegurar a todos existência digna, conforme os ditames da justiça social» ${ }^{5}$.

Dentro desta lógica, a ordem econômica brasileira, necessariamente, observará os princípios da soberania nacional, da propriedade privada, da função social da propriedade, da livre concorrência, da defesa do consumidor, da defesa do meio ambiente (com tratamento diferenciado de acordo com o impacto ambiental dos produtos e serviços e dos respectivos processos de elaboração e prestação), da redução das desigualdades regionais e sociais, da busca do pleno emprego, e do tratamento favorecido para as empresas de pequeno porte com sede no Brasil.

No âmago desta perspectiva, os ditames da ordem econômica brasileira são resguardados sempre, e quando, as entidades empresárias atuam com responsabilidade social, impedindo que essas atividades submetam o entorno, as pessoas e o meio ambiente natural a riscos que possam conspurcar a qualidade de vida e o desenvolvimento sustentável.

Por conseguinte, e considerando o aspecto de sociabilidade, e solidariedade até, que emergem do sentido dos valores sociais do trabalho e da livre iniciativa, a Constituição brasileira estimula e reconhece o

3 Arizmendiarrieta, José Maria: Pensamientos. Caja laboral Popular, Estella, 1983, p. 67.

${ }^{4}$ Grau, Eros R.: A ordem econômica na Constituição de 1988. 3.ed. São Paulo, Malheiros, 1997, p. 53.

5 Brasil: Constituição da República. 1988. Disponível em: http://www.planalto.gov. br Acesso em 12 out. 2020. 
Cooperativismo, conferindo tratamento tributário diferenciado para as sociedades cooperativas ${ }^{6}$.

Este 'olhar constitucional' decorre, sem sombra de dúvidas, do reconhecimento da pauta primordial da cooperatividade, que tem no homem o início e o fim de uma estratégia sócio-econômica-moral, elaborada com o propósito de emancipá-lo das diferentes dificuldades que oprimem sua realização pessoal e profissional, despertando-Ihe um sentimento de fraternidade e de preocupação com o meio 7 .

Portanto, necessário examinar-se o fator da responsabilidade social, associando sua análise operacional no âmbito do Cooperativismo, haja vista a recenticidade da própria responsabilidade social como fenômeno sócio-político jurídico, cuja referência se consolida somente a partir da década de $1980^{\circ}$.

Isto, sem qualquer dúvida, mostra-se transcendental, uma vez que a percepção sobre o sentido e efetividade da responsabilidade social, integrada ao exercício das atividades empresariais, determina a necessária alteração da postura atitudinal no relacionamento dos agentes de mercado durante o relacionamento com o entorno onde as entidades encontram-se inseridas, com os seus clientes, colaboradres e com o meio ambiente natural.

Este detalhe, o traço atitudinal das organizações empresariais, durante o exercício das atividades mercadológicas, integra o substrato axio-principiológico representativo dos valores e princípios que forjaram a identidade do Cooperativismo, desde a constituição da sociedade cooperativa dos Probos Pioneiros de Rochdale, em 1844, na cidade de Manchester, na Inglaterra.

Assim sendo, o presente trabalho desenvolverá uma abordagem sobre a representatividade e o significado da responsabilidade social no ambiente do Cooperativismo. Para tanto, examinará as questões inerentes à liberdade para o exercício da atividade empresarial, a responsabilidade social como prerrogativa de resgate do socialis et adminicula hominum, o significado de identidade cooperativa, e a responsabilidade social como uma questão de causa e efeito do Cooperativismo.

6 Conforme os artigos 173, II, c, e 174, § 2. ${ }^{\circ}$, da Constituição Federal (Brasil, 1988).

7 Miranda, José Eduardo de: De la crisis de identidad al rescate de la génesis del cooperativismo. Madrid, Dykinson, 2012, p. 15.

8 Confederação Nacional da Indústria: Responsabilidade social empresarial. CNI, Brasília, 2006, p. 09. 


\section{Ponderação preliminar: da livre iniciativa à liberdade para o exercício da atividade empresarial}

Para um entendimento pertinente do sentido da liberdade do exercício da empresa, deve-se, prioritariaemnte, compreender a sua natural interdependência com a livre iniciativa, representando, em sua complexidade, a liberdade da iniciativa econômica privada. Importante, pois, assinalar que, de acordo com o que se apreende da pauta normativa dos artigos $1 .^{\circ}, \mathrm{IV}^{9}$, e $170^{10}$, da Constituição da República Federativa do Brasil, a liberadade para o exercício da atividade empresarial conforma-se como um atributo-aptidão de caráter principiológico.

Preliminarmente, deve-se registrar que a livre iniciativa, de acordo com a acepção que emerge do inciso IV, do artigo $1 .{ }^{\circ}$, revela-se como um princípio constitucional fundamental, servindo de amparo do marco de princípios estabelecidos pelo constituinte originário, conformando a perspectiva de instauração de uma nova ordem. Por isto, enquanto princípio fundamental originário, a livre iniciativa destaca-se como um dos núcleos "sensíveis da Constituição Federal, de tal modo que o constituinte derivado neles encontra a condição fundamental de seu exercício» ${ }^{11}$.

Dentro desta ótica, tem-se que o símbolo da fundamentalidade, na medida em que converte a livre iniciativa numa coluna normativo-principiológica intangível, que oprime qualquer interpretação limitativa de seu alcance, fraciona-o numa cadeia de direitos, garantias e deveres inseparáveis da dignidade da pessoa humana12.

Ressalta-se, portanto, que a livre iniciativa, porquanto um fundamento da República Federativa do Brasil, exprime uma hipótese socialmente importante ${ }^{13}$, reveladora de bem-estar e de justiça social, em que «cada um deve poder dispor dos meios materiais para viver con-

9 Art. 1. ${ }^{\circ}$ A República Federativa do Brasil, formada pela união indissolúvel dos Estados e Municípios e do Distrito Federal, constitui-se em Estado Democrático de Direito e tem como fundamentos: (...) IV - os valores sociais do trabalho e da livre iniciativa; (...) (Moraes, Alexandre de: Constituição do Brasil interpretada e legislação constitucional. 5 ed. São Paulo, Atlas, 2005, p.130).

10 Ibid., p. 1950.

11 Júnior, Tércio Sampaio Ferraz: Livre-iniciativa. Propaganda de alimentos e competência da anvisa. In Gaban, Eduardo Molan e Domingues, Juliana Oliveira: Estudos de direito econômico e economia da concorrência. Curitiba: Juruá, 2009, p. 50.

12 Ibid., p. 50.

13 Da Silva, José Afonso. Curso de direito constitucional positivo. 26 ed., São Paulo, Malheiros, 2006, p. 202. 
fortavelmente segundo as exigências de sua natureza física, espiritual e política» ${ }^{14}$. É dentro desta dinâmica de significado, que a livre iniciativa alcançará legitimidade sempre e quando for exercida no interesse da justiça social.

Ao contrário, diz-se que «será ilegítima, quando exercida com o objetivo de puro lucro e realização pessoal do empresário. Daí por que a iniciativa econômica pública, embora sujeita a outros tantos condicionamentos constitucionais, se torna legítima, por mais ampla que seja, quando destinada a assegurar a todos existência digna, conforme os ditames da justiça social» 15 .

Adiante, e muito embora o termo livre iniciativa mostre-se, a priori, como determinante da absoluta e irrefutável liberdade de ação, sua expressão revela-se como um indubitável princípio capital do liberalismo econômico, a livre iniciativa surgiu para promover a libertação de agentes econômicos primitivos, dos vínculos opressores e limitadores oriundos do período feudal.

Constata-se, deste modo, que até meados do século xx, a livre iniciativa econômica oferecia uma «garantia aos proprietários da possibilidade de usar e trocar seus bens; garantia, portanto, do caráter absoluto da propriedade; garantia de autonomia jurídica e, por isso, garantia aos sujeitos da possibilidade de regular suas relações do modo que tivessem por mais conveniente; garantia a cada um para desenvolver livremente a atividade escolhida» ${ }^{16}$.

Fato patente é que o princípio da livre iniciativa conjuga-se com a ideia de liberdade de empresa dentro de sua prerrogativa semântica, que denota a empresa como atividade econômica organizada, para circular produto/bem ou serviço, mostrando-se, substancialmente, como o «resguardo jurídico ao agente econômico de empreender o que desejar sem interferência estatal. Corresponde, na esfera econômica, à proteção jurídica dispensada ao cidadão, no âmbito político» ${ }^{17}$.

Sinteticamente, pode-se aferir que a livre iniciativa materializa-se no contexto constitucional com o objetivo de viabilizar «uma esfera de liberdade de atuação no mercado para que os indivíduos possam atuar na busca de seus interesses, e, com isso, promover o

14 Ibid., p. 789.

15 Da Silva, p. 794.

16 Ibid., p. 794.

17 Aguillar, Fernando Herren: Direito econômico: do direito nacional ao direito supranacional. 2ed. São Paulo, Atlas, 2009, p. 257. 
desenvolvimento» ${ }^{18}$. Isto, é consabido, não significa que a liberdade de empresa menospreze a dignidade humana, as questões sociais e a defesa do meio ambiente.

\section{A responsabilidade social e a redenção do socialis et adminicula hominum}

A fenomenologia que opera a conjugação entre o exercício da empresa e a responsabilidade social, desvela a percepção de que a gênese especulativa do mercado de circulação de bens e serviços sofre uma considerável transmutação de valores. Com a responsabilidade social inserida no universo das entidades empresariais, e mesmo daquelas que não se revestem da qualidade empresarial, a lógica operacional estampa que as relações de mercado não mais se desenvolvem com base num intuito unicamente material, de aspecto lucrativo.

O certo é que a responsabilidade social provoca uma completa ruptura no paradigma tradicional dos negócios, que historicamente sobrelevou o lucro, desprezando as pessoas, o meio e o próprio entorno de inserção da entidade.

Portanto, cogitar a atuação socialmente responsável pressupõe ir além do cumprimento da lei, pois a vazão principiológica da responsabilidade social reclama a observação de uma plataforma de valores, e o levante de um sentimento indispensável à subtração do intuito de lucro como objetivo primoridial do negócio.

Sobre este aspecto, não se pode esquecer que «a moral é um fato histórico e, por conseguinte, a ética, como a ciência da moral, não pode concebê-la como dada de uma vez para sempre, mas tem de considerá-la como um aspecto da realidade humana mutável com o tempo ${ }^{19}$. A mutabilidade da moral, ao longo do tempo, e no decorrer da história, alcança de sobremodo o sistema econômico, contaminando a atitude e a perspectiva dos agentes do mercado.

Esta metamorfose atitudinal provocada pela inserção da responsabilidade social no cenário de mercado de bens e serviços «pode ser traduzida como um princípio ético, aplicado à realidade através de uma gestão que leva em consideração as necessidades e opiniões dos dife-

18 Sacchelli, Roseana Cilião: A livre iniciativa e o princípio da função social nas atividades empresariais no contexto globalizado. In Revista da AJURIS. v. 40 -n. 129Março 2013. Disponível em http://www.ajuris.org.br/OJS2/index.php/REVAJURIS/article/ view/315/250 Acesso em 09 set 2020.

19 Vasquez, Adolfo Sánchez. Ética. 1990, p. 23. 
rentes stakeholders, isto é, dos públicos envolvidos ou impactados pelo negócio das empresas: clientes, funcionários, acionistas, comunidades, meio ambiente, fornecedores, governo e outros» 20 .

Há, assim, uma conjunção de elementos que despertam o olhar cauteloso também por parte do público que se relaciona com as entidades empresariais. "Quando uma nova empresa abre suas portas para a comunidade, ela também, abre a porta para um conjunto de obrigações que ultrapassam a tarefa de comprar ou vender, produzir ou distribuir. Junto com a obrigação de ser uma possibilidade de bom crédito - pagando suas contas, pagando seus impostos - ela assume a obrigação de ser uma boa 'cidadã' e uma boa vizinha (...) Se um negócio adotar práticas que estejam contra o interesse público, o público irá procurar o regulamento para corrigir a prática» ${ }^{21}$.

Em vista disso, observa-se uma quantidade considerável de iniciativas que buscam construir o conceito de responsabilidade social no ambiente das atividades de mercado, para que melhor se possa compreender a dimensão do seu significado.

Nota-se, assi, que, "para uns é tomada como uma responsabilidade legal ou obrigação social; para outros, é o comportamento socialmente responsável em que se observa a ética, e para outros, ainda, não passa de contribuições de caridade que a empresa deve fazer. Há também, os que admitam que a responsabilidade social seja, exclusivamente, a responsabilidade de pagar bem aos empregados e dar-lhes bom tratamento. Logicamente, responsabilidade social das empresas é tudo isto, muito embora não sejam, somente, estes itens isoladamente» ${ }^{22}$

Em linhas gerais, a responsabilidade social representa o compromisso que as organizações devem nutrir em relação à sociedade, "expresso por meio de atos e atitudes que afetem positivamente, de modo amplo, ou a alguma comunidade, de modo específico, agindo positivamente e coerentemente no que tange a seu papel específico na sociedade e sua prestação de contas para com ela» ${ }^{23}$.

20 BSD: Responsabilidade social empresarial. Disponível em http://www.inmetro. gov.br/multiplicadores acesso em 17 set 2020.

21 Lundborg, Louis. Public relations in the local community. 1950, p. 4-15.

22 Zenisek, Thomas J.: Corporate social responsability, a conceptualization based on organizational literature. Apud OLIVEIRA, José Arimatés de. Responsabilidade social em pequenas e médias empresas. In Revista de Administração de Empresas, 24 (4): 204, out./dez.1984.

${ }^{23}$ Cardoso, Alexandre J. G.: A responsabilidade social nos negócios: um conceito em construção. In Ashley, Patrícia Almeida (org.). Ética e responsabilidade social nos negócios. São Paulo, Saraiva, 2002, p. 6. 
Aqui, é primordial salientar que em virtude da essencialdiade da resposta socialmente adequada, as organizações assumem uma «obrigação de caráter moral, além das estabelecidas em lei, mesmo que não diretamente vinculadas a suas atividades, mas que possam contribuir para o desenvolvimento sustentável dos povos. Assim, numa visão expandida, responsabilidade social é toda e qualquer ação que possa contribuir para a melhora da qualidade de vida da sociedade ${ }^{24}$.

As açôes configurantes de um efetivo exercício de responsabilidade social emergem da ponderação sobre as estratégias e os impactos que as decisões podem provocar no contexto social e na vida das pessoas. Para isto, urge que os líderes empresariais celebrem um comportamento ético e transparente, que convirja à sustentabilidade como um todo, sem exceção. Com isto, as entidades empresárias tanto atuarão em benefício da maximização de um impacto positivo de suas atividades no ambiente social em que se encontram inseridas, como potencializarão o seu prório retorno econômico.

Distante de qualquer devaneio, pode-se afirmar que a responsabilidade social diz respeito ao conjunto de iniciativas planejadas e executadas pelos exercentes das atividades negociais para a materialização de ações que respondam preocupações «de natureza ética, social, e ambiental às suas interações com clientes, colaboradores, fornecedores, concorrentes, acionistas, governos e comunidades» ${ }^{25}$.

Mesmo que a ética seja compreendida como um de conjunto de premissas que permitam uma conclusão radical de que o bem é o bem, «hay que procurar que no se mezcle com trazas de mal bajo ninguna circunstancia, porque entonces dejaría de ser bien proclamado ${ }^{26}$.

A bem da verdade, o histórico das políticas econômicas, entabuladas para nortear o desenvolvimento das atividades de mercado, deixa transparecer que "en ocasiones, algunos «expertos» en ética —al igual que sucede en ciertos economistas - parecem olvidar la realidad real sobre el que el mundo deberia asentarse. Formulan principios silogísticos que pueden tener una buena lógica interna, pero que son totalmente inaplicables a la realidad, porque la desconocen ${ }^{27}$.

Talvez como causa do entendimento desta lógica que o Instituo Ethos deixa em evidência que a «responsabilidade social empresarial é a forma de gestão que se define pela relação ética e transparente da

24 Ibid., p. 7.

25 Confederação Nacional da Indústria, 2006, p. 47

26 Aguado, Javier Fernández. Ética y rentabilidad en la empresa. In Heredia, Pablo.

J. B. (Coord.): Ética y actividad empresarial. Madrid, Minerva Ediciones, 2004, p,17.

27 Ibid., p. 18. 
empresa com todos os públicos com os quais ela se relaciona e pelo estabelecimento de metas empresariais que impulsionem o desenvolvimento sustentável da sociedade, preservando recursos ambientais e culturais para as gerações futuras, respeitando a diversidade e promovendo a redução das desigualdades sociais» ${ }^{28}$.

Por isto, salienta-se que a 'conexão' desenvolvida com todos os diferentes perfis de público que celebram relações com a empresa, preconiza o estabelecimento de um olhar diferenciado também para os colaboradores da entidade, oportunizando-lhes os meios adequados à maximização de sua autoestima, capacidade relacional, sustentabilidade emocional, e realização pessoal e profissional.

Agir de maneira ética, prenunciativa de um exercício socialmente responsável, implica no desenvolvimento de uma atiude empresarial atenta às necessidades das pessoas e do meio. Esta afirmação, por certo, solidifica a ideia de que a responsabilidade social traduz todo o tipo de iniciativa empreendia pela empresa, com o propósito de provocar a mudança da realidade das pessoas, seja através de ações que alcancem diretamente o sujeito a que se destina, seja pela articulação de expedientes implementados no âmbito comunitário.

Pela inteligência dos preceitos que emergem do artigo 170, da Constituição Federal, entende-se que a existência digna de todos é o fim primeiro da ordem econômica. Compulsando-se, destarte, a noção de existência digna de todos sob a supremacia da dignidade da pessoa humana, em interdependência com o seu marco de enquadramento conceitual, fica evidente que a responsabilidade social incorpora a ordenação econômica de maneira ativa e normativa, provocando, ou determinando, um comportamento ético-moral que deve ser observado por todos os agentes de mercado, independentemente de sua natureza.

Entende-se, com isto, que a partir do ano de 1988, com a promulgação da Constituição Federal brasileira, toda a legislação infraconstitucional elaborada para normatizar as atividades econômicas de mercado, e cada uma das organizações empresarias, precisam assentar-se sobre uma plataforma ética, que transpareça a preocupação pela qualidade de vida do homem, e pela transcendência das condições do meio. «La ética, en su función normativa, tendrá mucho que decir sobre los medios, los fines, las intenciones y las circunstancias en que se desarrolla la labor mercantil» 29 .

28 Instituto Ethos: O que é SER? 2011. Disponível em www.ethos.org.br/EthoWeb/ pt/29/o_que_e_rse Acesso em 14 set 2020.

29 Aguado, 2004, p. 23. 
Esta plataforma ética traduz o exercício empresarial socialmente responsável, definitivo para que as pessoas compreendam o sentido soberano da fraternidade, da solidariedade e da sociabilidade, contribuindo, umas com as outras, para que todas alcancem o seu mais importante objetivo na vida: a felicidade. "Sucede que la ética es, en efecto, la ciencia de la felicidad. Pero ésta no es normativa. Por eso, junto con esa meta clara, es preciso contar con un conjunto de normas objetivas que permitan no desviarse de la senda. El tercer elemento es muy personal: los necesarios hábitos para poder cumplir esas normas que nos conducen hacia la felicidad posible ${ }^{30}$.

A constância, e, sobretudo, a efetividade no desenvolvimento e execução de práticas socialmente responsáveis, cultivam na atitude de cada indivíduo que se relaciona com a entidade negocial uma tendência a estabelecer uma forma distinta de enxergar as pessoas. Suplantando a postura egoísta e a atitude mecânica, unicamente material, as pessoas passam a se preocupar reciprocamente uma com as outras, de forma que todas, em conjunto, integrarão um processo sistêmico indispensável à redenção do socialis et adminicula hominum.

\section{Ponto determinante: o que é a identidade cooperativa?}

Ao observar-se todas as características que marcaram os traços da personalidade humana em distintos momentos da história, pode-se afirmar que o indivíduo não é um ser perfeito, constituindo-se, no todo, de uma parte que é boa, e outra que leva-o à inclinação para o mal.

Seu lado bom, por certo, resulta como um produto dos traços de uma personalidade solidária, fraterna e caridosa, que opera em benefício da construção de conceitos e atitude que viabilizem o alcance das condições de justiça, de igualdade, de liberdade, de dignidade, e de caridade. "Estas son las que pudiéramos llamar «nobles tendencias del alma» que nacen con la persona y la acompañan durante su vida. Como la civilización y el progreso de la Humanidad requieren que las personas trabajen en común, casi todos los sistemas económicos o políticos tratan de dar una solución que resuelva con equidad la convivencia y actividad del hombre en relación con el grupo.»31

30 Ibid., p. 21.

31 Abad Colas, G.: La empresa cooperativa. Zaragoza, Centro Nacional de Educación Cooperativa, 1977, p. 5. 
Justamente dentro desta expectativa, de ajustar-se como uma medida de resolução de diferenças, satisfação de necessidades e adequação das relações interpessoais, no ambiente de coletividade, o Cooperativismo surgiu como uma força que foi acolhida por diferentes regimes políticos, e, muito rapidamente, após a exitosa e formal experência dos Probos Pioneiros de Rochdale no ano de 1844, em Manchester, na Inglaterra, espalhou-se pelo mundo.

O elemento significativo na prática dos Probos de Rochdale, que resultou expresso por seus estatutos, foi o incontável número de benefícios que a ação cooperativa, celebrada através de uma associação de pessoas que compartilhavam necessidades e sentimentos de humanidade, disseminou em diferentes contextos existenciais, alavancando estratégias que enalteciam a fraternidade, a solidadariedade e a dignidade humana.

Não se pode, jamais, olvidar que a transformação socio-econômica-moral que os Probos Pioneiros de Rochdale promoveram no entorno em que a sociedade cooperativa foi constituída, permite acreditar que a natureza humana manifestou-se de maneira diferente em Rochdale, pois «de ninguna otra manera se puede explicar el hecho de que hayan dominado el arte de actuar en conjunto y mantenerse juntos, como no lo había hecho ningún otro grupo de trabajadores en Gran Bretaña» ${ }^{32}$.

Considerando-se detalhadamente a pauta estatutária da organização, alicerçada sobre valores e princípios que enaltecia o valor e o respeito à condição humana, hoje, não restam dúvidas de que os Probos de Rochdale foram impregnados por uma sensibilidade ética que os levou a obrar na busca pela satisfação de suas carências, solidarizando-se na composição de alternativas que viabilizassem o suplante das carências daqueles que integravam o entorno social onde a cooperativa foi implantada.

O fato representativo na construção de uma entidade fortalecida por valores e princípios humanos, é que nenhum dos precursores possuíam qualquer formação especial, que os legitimasse uma reflexão global, indispensável para uma atuação sistêmica e holística, em benefício do todo, e não apenas de alguns.

Reféns dos arrazadores reflexos provocados pela Revolução Industrial, os Probos de Rochdale criaram uma cooperativa que reagiu à desordem e a mséria impostas pelo capitalismo desumano. "Sin embargo, su finura ética fue extraordinaria» Algunos botones de su actuación

32 Birchall, J.: Discurso de apertura. in Revista de la Cooperación Internacional. 28, 1, ACl, 1995, p. 18. 
son: «la regla de la pureza y exactitud en el peso y medida de los productos contra la adulteración de los artículos y el fraude; preocupación por los precios justos; el retorno como devolución de lo que se habría cobrado de más; la legitimidad del interés del capital aunque lo limitaban para no incurrir en prácticas capitalistas; reparto del excedente entre los socios o prorrata de sus compras, que respeta al gran principio de la ética de los intercambios que es el de la equivalencia de las contraprestaciones recíprocas; dedicación de una parte de los excedentes a obras sociales. $\rangle^{33}$

Os Probos de Rochdale, considerados ainda hoje como os precursores do Cooperativismo moderno, envoltos em uma gama de questões que afetavam sua sobrevivência, não se furtaram de discutir e deliberar sobre problemas humanos e morais, aplicando ao caráter cooperativo do seu negócio um espírito ético que norteou a ideologia e construção do Cooperativismo como um sistema econômico e social ${ }^{34}$.

Este matiz ideológico, é sabido por todos, perdeu-se no entremeio do século $\mathrm{xx}$, provocando uma crise identitária que quase erradicou o Cooperativismo, haja vista «la fuerte tendencia entre los cooperativistas de esquivar la teoría y la ideología y en su lugar "ir bien con los negocios" $\gg^{35}$.

Acontece que «a menudo se ha pensado que una rígida aplicación de la letra de estas reglas era suficiente para crear una auténtica cooperativa capaz de lograr el éxito ${ }^{36}$. A ausência de um relacionamento profícuo com o núcleo da ideología cooperativa, a falta de preparo de administradores, sócios e colaboradores, e a necessidade de manter-se próxima do perfil dos concorrentes no mercado econômico, determinou uma crise de identidade no Cooperativismo, e a consequente mortalidade de cooperativas em todos os rincões do Planeta ${ }^{37}$.

Para impedir o alastramento da crise, e buscar uma alternativa de resgate da essência que motivou os Probos de Rochdale a demarcarem a história por sua ação cooperativa, a Aliança Cooperativa Internacional instaurou um grande movimento internacional, direcionado ao

33 Aranzadi Telleria, D.: Credibilidad del cooperativismo. in Anuario de Estudios Cooperativos. 1999. Bilbao, Universidad de Deusto, 1999. p. 161

34 Lasserre, G.: El hombre cooperativo. Buenos Aires, Intercoop Editora Cooperativa Limitada, 1980, p. 214.

35 Ladilaw, A. F.: Las cooperativas en el año 2000. México D. F., ACl-Confederación Mejicana de Cajas Populares, 1981, p. 27 y 28.

36 Lasserre, 1980. p. 214.

37 Benevides Pinho, D.: Evolución del pensamiento cooperativista. Buenos Aires, Intercoop Editora Cooperativa Limitada, 1987, p. 137. 
reexame dos valores básicos, dos propósitos e dos princípios que deram sustentação ao Cooperativismo.

Após uma série de estudos e pesquisas, a Aliança Cooperativa Internacional promulgou a Declaração sobre a Identidade Cooperativa no ano de 1995, em Manchester, durante o Congresso de celebração de seu centenário. A declaração de identidade consolidou a base ideológica do Cooperativismo, estruturada em três vérticies distintos, que se intercomunicam para assegurar a identidade cooperativa: i) o conceito de sociedade cooperativa; ii) os valores cooperativos; e, iii) os princípios cooperativos.

Relativamente ao conceito de sociedade cooperativa, a Declaração emitida pela $\mathrm{ACl}$ é peremptória no sentido de definí-la como uma «associação autônoma de pessoas que se unem de forma voluntária para satisfazer suas necessidade e aspirações econômicas, sociais e culturais em comum, através de uma empresa de propriedade conjunta e de gestão democrática» ${ }^{38}$.

No tocante aos valores cooperativos, é importante assinalar que a história da cooperação deixa em evidência que todos os cooperacionistas sempre compartilharam de valores que acabaram por humanizar o exercício da cooperatividade. "Se ha dado por sentado que, a pesar de las diferencias que existen en sus campos de actuación, entornos de trabajo y tareas prácticas, las sociedades cooperativas que existen en el mundo entero tienen, debido a sus valores básicos comunes, suficientes aspectos en común como para darle al movimiento cooperativo un carácter uniforme. ${ }^{39}$

Talvez, por isto, a Aliança Internacional Cooperativa entendeu que o resgate da identidade do Cooperativismo estava condicionado à promulgação dos valores que sempre foram inatos à cooperatividade, e acabaram adormecidos, ou melhor, esquecidos. Foi, então, que a Declaração sobre a Identidade dividiu os valores cooperativos em dois grupos, denominados de valores fundamentais e valores éticos. O primeiro grupo, composto pelos valores da autoajuda, autorresponsabilidade, democracia, igualdade e solidariedade, além de orientar à estruturação da sociedade cooperativa, estão diretamente relacionados à forma pela qual serão desenvolvidas as atividades durante o exercício do negócio. Já, o segundo grupo, constituído pelos valores da honestidade, trans-

$38 \mathrm{ACl}$. Declaración de la Alianza Cooperativa Internacional sobre la Identidad Cooperativa aprobada en Manchester. Vitoria-Gasteiz, Consejo Superior de Cooperativas de Euskadi, 1996, p. 35

39 Suomela, K.: Los valores básicos de las cooperativas de consumo. In Revista de la Cooperación Internacional. 24, 1, ACl, 1991, p. 11. 
parência, responsabilidade e vocação social, possui um aspecto moral que destaca as principais características que devem possuir as pessoas envolvidas diretamente com a cooperativa, sejam cooperados, coloboradores, e mesmo tercerizados.

Por fim, em relação aos princípios cooperativos, em Manchester, no ano de 1995, "la Alianza ha establecido que los principios pierden la singularidad reglamentaria, y ganan un perfil paradigmático, puesto que a la vez representan un modelo de pautas para evaluar el comportamiento y para tomar decisiones ${ }^{40}$, servindo, ao mesmo tempo, de pauta pela qual as cooperativas colocam em prática os seus valores.

É nesta linha de orientação, que a Declaração sobre a Identidade Cooperativa dispõe que os princípios cooperativos são: adesão voluntária; gestão democrática por parte dos sócios; participação econômica dos sócios; autonomia e independência; educação, formação e informação; cooperação entre as cooperativas; compromisso com a comunidade.

Equalizando todas as situações que afetaram o matiz identitário do Cooperativismo, e considerando a essência nuclear da Declaração sobre a Identidade Cooperativa, emitida pela Aliança Cooperativa Internacional em 1995, no Congresso de Manchester, deve-se levar em consideração dois fatores essenciais, para que se possa compreender o significado da identidade cooperativa.

Em primeiro lugar, é necessário entender-se que o termo identidade compreende o conjunto de características, ou atributos, que, uniformizados entre si, são utilizados para distinguir pessoas, coisas ou entidades. Deste modo, a partir da distinção de uma para outra, é possível individualizá-la, de maneira que se consiga interpretar sua gênese, dimensionando sua particularidade. A identidade, portanto, perfaz os traços que servem para dizer o que uma pessoa, uma coisa, ou uma entidade efetivamente é.

Por isto, em segundo, a compreensão da identidade não resulta da associação fragmentada de algum, ou alguns dos elementos que integram a Declaração sobre a Identidade, às sociedades cooperativas. Se a Declaração conjunga o conceito, os valores e os princípios como os elementos de sustentação da identidade de uma coopertativa, a inobservância à unificação dos componentes identitários fragiliza o substrato identitário, desnaturando a essência da cooperatividade.

40 Miranda, José Eduardo. Filosofía cooperativa: análisis del proceso de conformación del cooperativismo. Curitiba, Juruá, 2017, p. 124. 
Ressalta-se, com isto, que, da constituição, ao desenvolvimento de uma sociedade cooperativa, a preservação da identidade pressupõe resguradar a integridade do seu conceito, para a utilização dos seus princípios como pautas de aplicação dos valores. Não há, assim, que cogitar-se identidade para as cooperativas que preservam valores e princípios formalmente no corpo de seus estatutos, e atuam materialmente como entidades de capital, que enaltecem exclusivamente a importância do fator econômico, secundarizando, ou desprezando, a relevância das pessoas, do entorno e do meio ambiente natural.

\section{O emprego do princípio da educação e informação, como mote de difusão dos valores cooperativos: uma experiência prática alicerçada sobre a axiologia da cooperação, com o propósito de fortalecer a construção da cidadania e defesa do meio ambiente}

O termo Cooperação, que significa a ação de cooperar, provém do vocábulo idiomático cooperatio, de origem latina. Analiticamente, a expressão oferece uma ideia de atividade comum, que está associada ao próprio verbo cooperar, representativo de "obrar em conjunto com o outro, ou outros, para o mesmo fim» ${ }^{41}$. Sob este aspecto, encontramos na Cooperação uma forma de fazer, uma atividade e um efeito, um talante de comportamento social, e até mesmo um modo de viver, que presume uma relação corporativa e que tem como objetivo um fim último, arraigado no interesse prático para o alcance de um bem comum ${ }^{42}$. Talvez por isto que estudos mais profundos examinaram a Cooperação como norma ética e como processo social.

No âmbito da ética, a Cooperação se conforma como um dos valores de maior prestígio ao longo do desenvolvimento da história da

41 A palavra cooperação deriva da expressão latina cooperatio, vocábulo comparativo de «cum» (com, junto) e "operar» (obrar, trabalhar) e significa a conseqüência de «cooperar» (Espasa. Diccionario de la Lengua Española. Madrid: Espasa Calpe, 2001, p. 185).

42 Soldevilla y Villar manifesta que a Cooperação preenche nossa vida de relação social. Segundo o autor, "en el círculo íntimo familiar, en el trabajo, en la oficina, en el descanso o en la diversión, es decir, en todas las actividades sociales, económicas políticas, etcétera, está implícita esta idea primaria de asociación íntima» (Soldevilla y Villar, A. D.: El movimiento cooperativista mundial: sus orígenes, desarrollo y problema actual. Valladolid: Talleres Gráficos Ceres, 1973, p. 2). 
humanidade, chegando ao ponto de alguns filósofos a consideraram como sinônimo de sistema moral. Considerada como processo social, a Cooperação representou um dos mecanismos centrais do processo evolutivo e constituiu um papel fundamental na formação e transformação dos tempos.

Ao conjugarem-se os fatores ético-processo-social, a Cooperação se estabelece sobre um alicerce axiológico adequado à conformação de um plano de cidadania distinto daquele reconhecido no âmbito das "esferas político-diplomáticas e cívico-jurídica (ius soli, ius sanguini $)^{43}$ » e significa estar em gozo dos direitos políticos, podendo votar(cidadania ativa) e ser votado (cidadania passiva) nos processos de participação política» ${ }^{44}$. Não perfaz exagero, pois, dizer-se que a cidadania não possui «uma definição estanque, mas um conceito histórico, o que significa que seu sentido varia no tempo e no espaço ${ }^{45}$. Esta peculiaridade, por certo, "ocorre tanto em relação a uma abertura maior ou menor do estatuto de cidadão para sua população (por exemplo, pela maior ou menor incorporação dos imigrantes à cidadania), ao grau de participação política de diferentes grupos (o voto da mulher, do analfabeto), quanto aos direitos sociais, à proteção social oferecida pelos Estados aos que dela necessitam» ${ }^{46}$.

Ser cidadão, portanto, "é ter direito à vida, à liberdade, à propriedade, à igualdade perante a lei: é, em resumo, ter direitos civis, é também participar no destino da sociedade, votar, ser votado, ter direitos políticos» ${ }^{47}$. Visto deste modo, salta evidente que exercer a cidadania plena é ter direitos civis, políticos e sociais; é integrar-se a um determinado entorno com sentimento de pertencimento, exercendo-se a responsabilidade pela busca das melhores formas de materialização dos direitos formalmente postos na Ordem Constitucional.

Diante do rigorismo desta vertente, flutua cristalino que o Meio Ambiente ecologicamente saudável perfaz elemento de principal importância à existência humana, calcada em indicadores de dignidade. $\mathrm{Na}$ medida em que oferece ao homem os insumos que movimentam

43 Bittar, Eduardo C.B. Ética, educação, cidadania e direitos humanos: Estudos filosóficos entre cosmopolitismo e responsabilidade social. São Paulo. Manole, 2004, p. 9.

44 Ibid., p. 9.

45 Pinsky, Jaime \& Pinsky, Carla Bassanezi (org). História da cidadania. 2.ed. São Paulo:Contexto, 2008, p. 9.

46 Ibid., p. 9.

47 Pinsky \& Pinsky, 2008, p. 09. 
as atividades econômicas de mercado, o Meio Ambiente lhe proporciona os substratos naturais congêneres à qualidade de vida, a exemplo do ar, da água e do solo. Não obstante, detecta-se uma postura ambígua dos indivíduos em relação ao Meio Ambiente, pois, enquanto dele dependem, calam-se à sua responsabilidade de preservação e proteção.

Atentos à esta realidade, merece anotar que, hodiernamente, muito embora seja dependente do Meio Ambiente, o homem não lhe destina à atenção necessária, faltando-lhe, inclusive, com a responsabilidade. A colisão entre o binômio dependência-(des)responsabilidade, deriva da carência de uma consciência ecológica adequada, via-de-regra alcançada pelo fluxo de informações relacionadas aos efeitos provocados pelos uso desmedido dos recursos naturais, ferindo o suposto da sustentabilidade, preconizado pelo artigo 225 da Magna Carta, que é cristalino no sentido de que «todos têm direito ao meio ambiente ecologicamente equilibrado, bem de uso comum do povo, essencial à sadia qualidade de vida, impondo-se ao Poder Público e à coletividade o dever de defende-lo e preservá-lo para as presentes e futuras gerações» ${ }^{48}$.

Não há como descartar-se que o substrato axiológico da Cooperação pode representar papel sublime na conformação de novas posturas e atitudes cidadãs. Com o advento de normas e proteção ao Meio Ambiente, é patente a intenção de substituir-se a visão egocêntrica (antropocêntrica) que protagonizou os diferentes cenários até o fim do século XX, por outra, cuja proteção engloba todas as formas de vida: eis a visão biocêntrica, que situa a vida, como um todo, no centro da preocupação do Direito. Por esta trilha, o estabelecimento de práticas axiológicas cooperacionistas voltadas ao reenquadramento da cidadania, exsurge preponderante ao uso sustentável do meio, resguardando-se às gerações futuras o direito de utilizá-lo nas mesmas condições que se faz hoje, uma vez que:

O desenvolvimento sustentável, então, depende de uma efetiva transformação do homem. Esta transformação, é certo, se consuma quando o homem descobre sua importância diante do meio, a importância do meio onde habita, e, por suposto, a importância daqueles que compartilham do meio com ele. A exemplo do que ocorreu nos primórdios da história, também hoje a consciência pelo valor do coletivo, pela importância do todo, há de resgatar o agir cooperativo

48 Brasil. Constituição Federal. Vade mecum 2014. São Paulo : RT. 2014, 88. 
como fenômeno social-solidário, intrínseco a vida em comunidade hoje e amanhã. ${ }^{49}$

Compreende-se, assim, que a solução para os problemas de detração à sustentabilidade, encontra guarida num processo sistêmico de desenvolvimento de uma consciência ecológica, estabelecida a partir de um matiz da cidadania como predicado daquele que pertence ao meio ambiente, e por ele é responsável para que se logre estabelecer mecanismos intrínsecos ao alcance de condições de dignidade. Neste sentido, implantou-se um Grupo de Pesquisa no Centro Universitário UNICNEC, na cidade de Osório, no Estado do Rio Grande do Sul, um Grupo de pesquisa constituído com o nome de Cidadania, Cooperação e Meio Ambiente. Formado sob o aspecto da multidisciplinariedade, o Grupo contou com a participação de alunos dos Cursos de Direito, Administração e Ciências Contábeis.

O interesse pela implantação do Grupo derivou do fato de o proponente manter um estrito relacionamento científico com o arcabouço axiológico da Cooperação, escrevendo e orientando pesquisas relacionadas aos valores cooperativos como instrumento de fortalecimento e/ ou resgate de entornos debilitados. Merece, portanto, destacar que a Cooperação é o remédio específico e inquestionável para todos os males sociais, "contribui para criar entre os cooperadores uma comunidade de interesses e a reuni-los por uma sociedade voluntária» ${ }^{50}$.

Buscou-se, assim, pelos trabalhos desenvolvidos pelo Grupo, ampliar os horizontes de inserção dos estudantes do UNICNEC de Osório, através de uma ação multidisciplinar própria para o resgate e/ou formatação da cidadania como elemento intrínseco ao pertencimento do indivíduo ao meio onde se encontra inserido, respondendo pela materialização de seus múltiplos anseios garantidos pelo Estado, em especial pela proteção do meio ambiente e pela consecução da dignidade da pessoa humana. Neste sentido, Grupo teve como objetivo geral, o «de analisar o desenvolvimento histórico do conceito de cidadania e o estudo do pressuposto cooperativo como elemento próprio à consolidação do exercício da cidadania para a defesa do meio ambient».

${ }^{49}$ Miranda, José Eduardo et. al. Meio Ambiente e Cooperação: os valores cooperativos como pressuposto de sustentabilidade. Boletín de la Asociación Internacional de Derecho Cooperativo. Boletín de la Asociación Internacional de Derecho Cooperativo. Bilbao: Universidad de Deusto, n. 44, 2010. p 17.

50 Salinas Ramos, F.: Temas cooperativos. Materiales de formación cooperativa. Madrid: Caritas Española, 1982, p. 23. 
Os objetivos específicos focaram: i) no entendimento da a amplitude do significado de cidadania, situando-a como mecanismo de pertencimento, que integra o indivíduo ao meio onde se encontra inserido; ii) no conhecimento dos fundamentos axiológicos do Cooperativismo, como instrumento apto ao exercício da cidadania, à defesa do meio ambiente; iii) no mapeamento das escolas de ensino fundamental, públicas, do município de Osório; iv) no estabelecimento de um canal de comunicação com alunos das séries iniciais, como forma de socialização do suposto axiológico da cooperação como instrumento próprio ao exercício da cidadania, à defesa do meio ambiente.

Cumpridos os procedimentos teóricos, de investigação e estudos, o Grupo realizou um levantamento quantitativo de escolas públicas, municipais e estaduais do município de Osório e estabelecer um mapeamento das práticas desenvolvidas em prol da defesa do meio ambiente e do exercício da cidadania. Posteriormente, executou-se atividades multiplicadoras dos valores da cooperação entre os estudantes de 08 a 14 anos, das escolas públicas, municipais e estaduais, do município de Osório.

Os principais impactos observados, a partir daingervenção do Grupo no ambiente das escolas, foi: i) promoção de uma consciência ecológica entre os estudantes e professores; ii) conscientização sobre a necessidade de uso sustentável dos recursos naturais; iii) desenvolvimento de práticas de consumo sustentável; iv) conhecimento sobre o sentido e a efetividade do pleno da cidadania; v) desenvolvimento de um novo padrão de identidade dentro do entorno, a partir de uma construção individual e coletiva dos jovens exercentes da cidadania; vi) estreitamento das relações entre a Universidade/Instituições Parceiras/Sociedade, como forma de consolidação da tríade ensino-pesquisaextensão, em prol da majoração das condições de bem-estar; vii) integração entre sociedade e academia, como pressuposto de consolidação da pesquisa científica. 


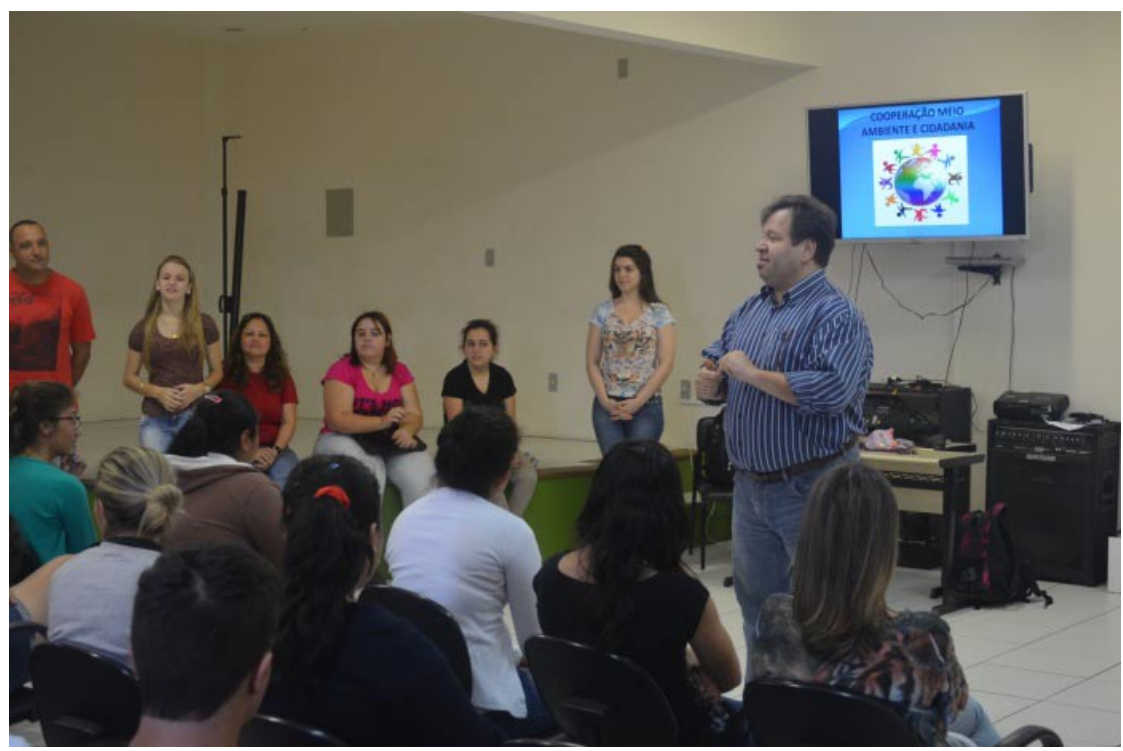

Oficina sobre valores cooperativos em escola estadual

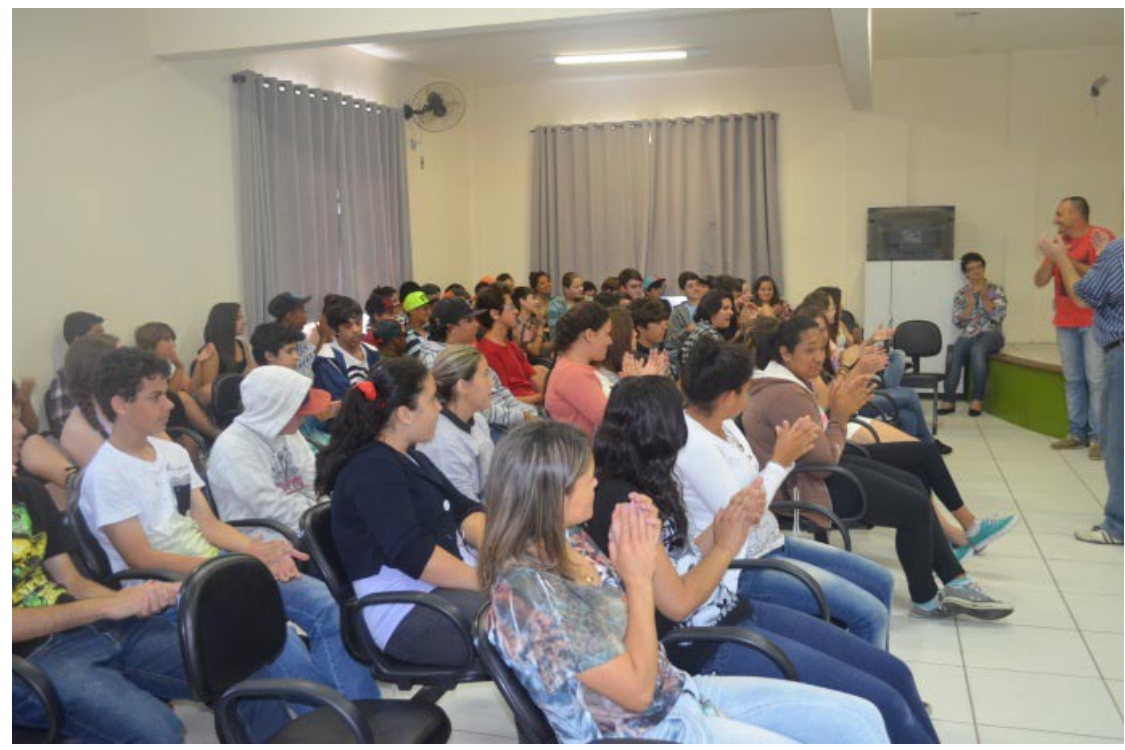

Oficina sobre valores cooperativos em escola estadual 


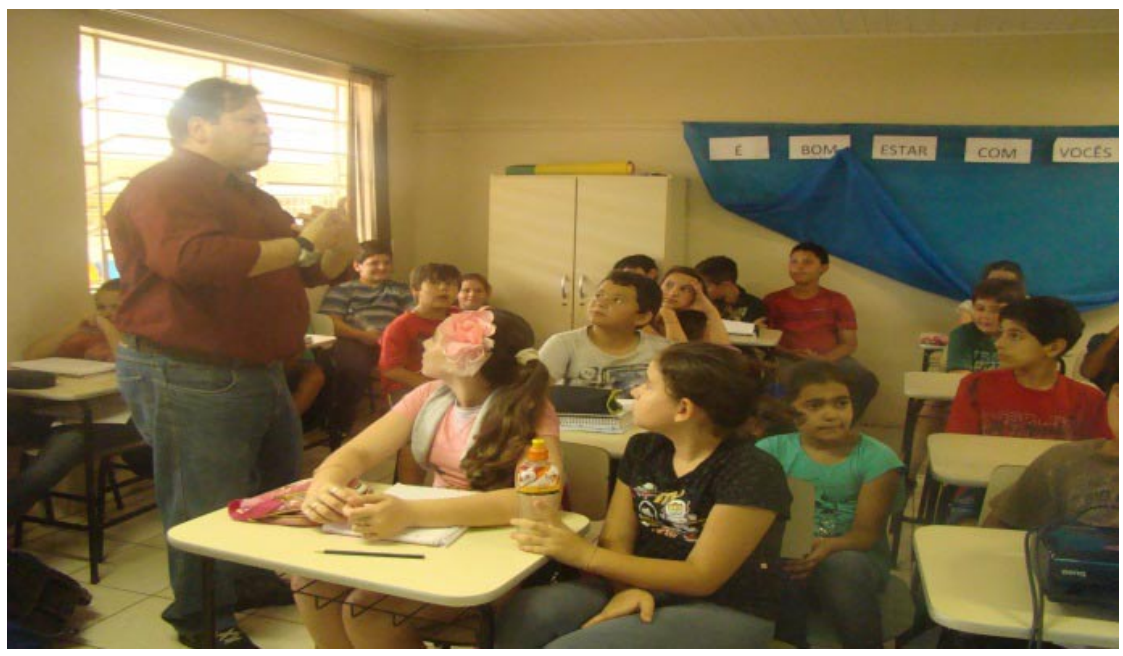

Oficina sobre valores cooperativos em escola municipal

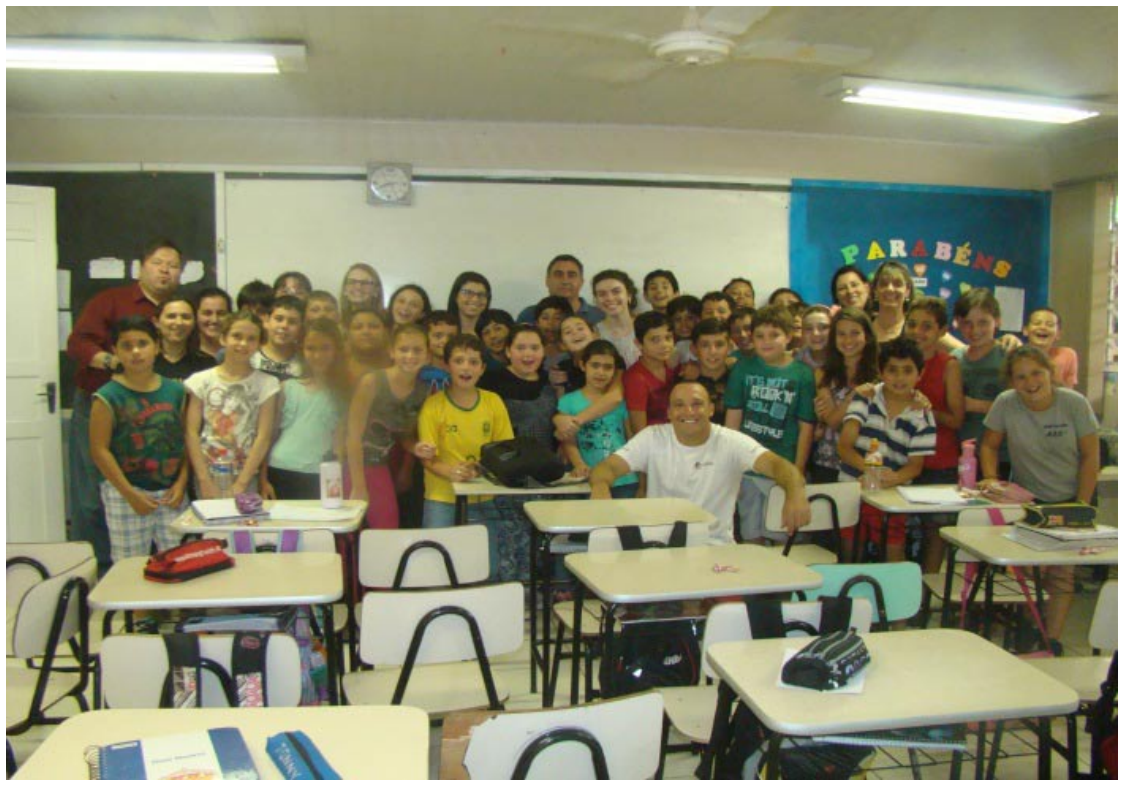

Oficina sobre valores cooperativos em escola municipal 


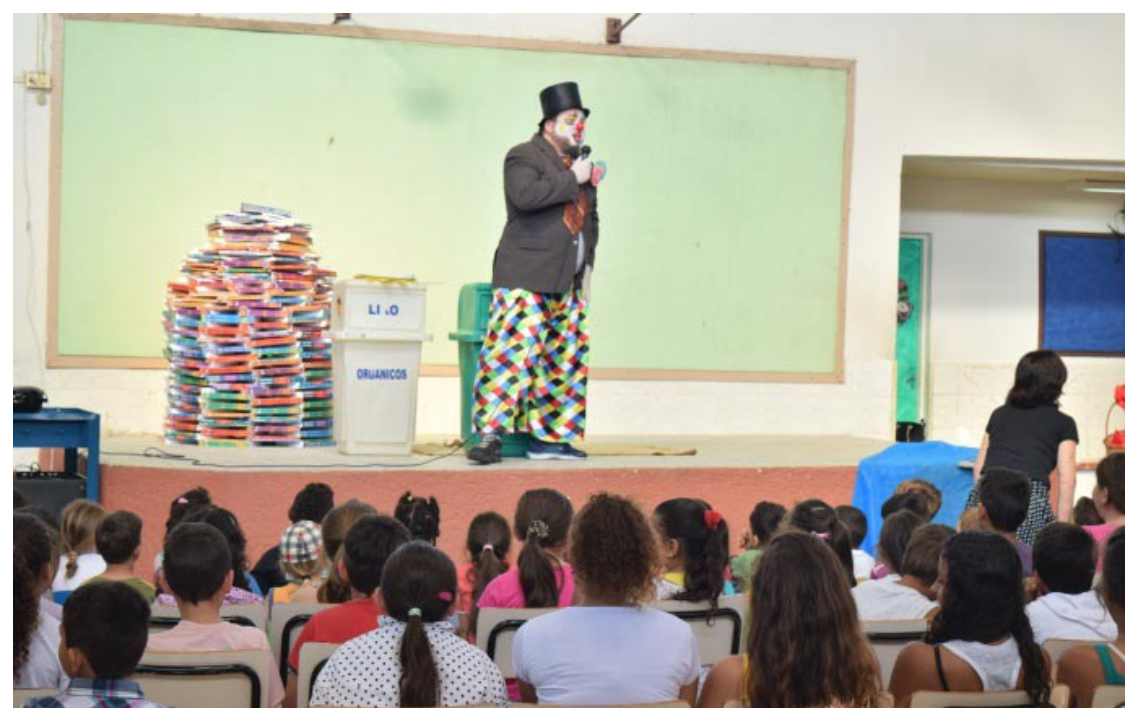

Projeto «O Circo da Cidadania: levando os valores cooperativos às escolas municipais de ensino fundamental»

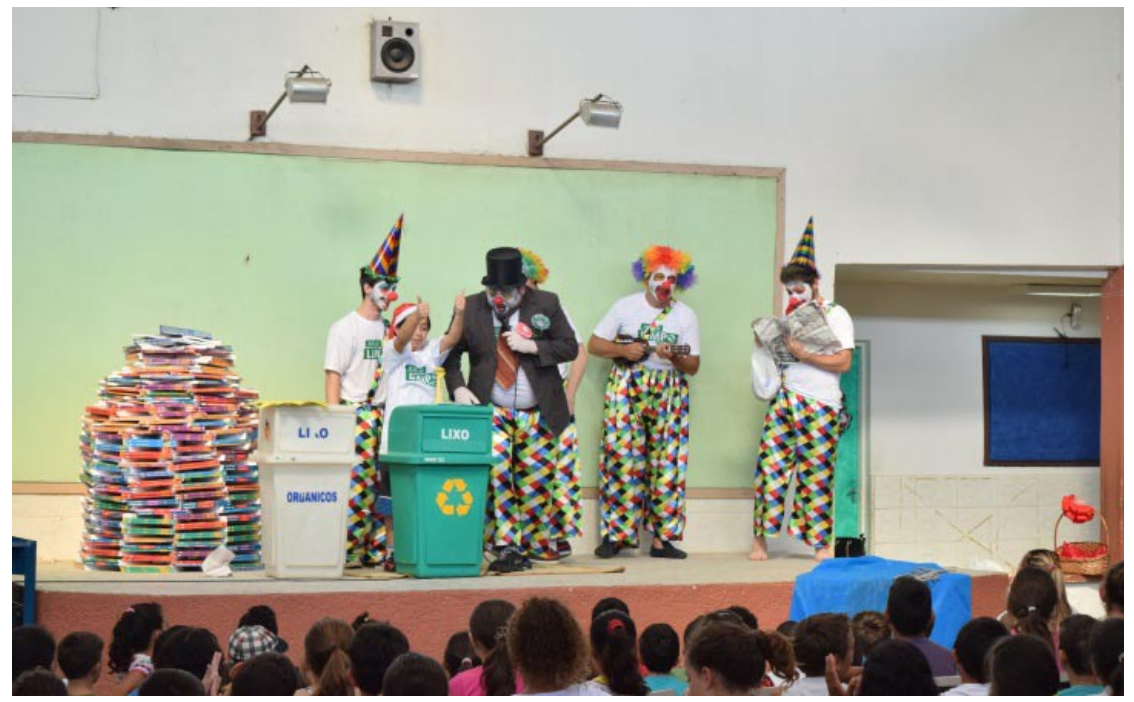

Projeto «O Circo da Cidadania: levando os valores cooperativos às escolas municipais de ensino fundamental» 


\section{A título de ultimas palavras: a responsabilidade social como causa e efeito do Cooperativismo}

Apreciando-se todas as transformações que se operam no mundo, hoje, e dimensionando-se todas as necessidades que exsurgem nos diferentes contextos da sociedade globalizada, não perfaz exagero dizer que os problemas sociais revelam-se como fertéis canteiros para a implementação de negócios, uma vez que as organizações empresariais tem a faculdade de «simultaneamente satisfazer uma necessidade social e ao mesmo tempo servir sua instituição, transformando a resolução de problema social numa oportunidade para negócios ${ }^{51}$.

Sequente por esta ótica, viu-se que a responsabilidade social, integrada no universo da empresarialidade, configura a integração de práticas desenvolvidas sobre uma plataforma ético-moral, que tem o propósito de viabilizar a sustenbilidade social e pessoal, através de ações que promovam o desenvolvimento das comunidades, a preservação do meio ambiente natural, a harmonização do ambiente de trabalho, a realização dos colaboradores e a satisfação das pessoas que negociam com a organização, tudo, além do retorno financeiro aos empresários ou acionistas.

De uma ou de outra forma, a responsabilidade social caracteriza-se por incentivar a elaboração de projetos que sejam efetivamente executados para: i) otimizar a sustentabilidade em todos os seus sentidos (social, econômica, cultural, política, humana); ii) alcançar a diversidade de públicos e meios integrados, ou adjacentes, ao exercício da empresa, oportunizando-lhes uma modificação positiva nas suas respectivas condições existenciais; iii) contribuir para o resguardo da dignidade humana e defesa do meio ambiente natural.

Impossível negar, com isto, que «ser socialmente responsável é um dos pilares de sustentação dos negócios, tão importante quanto a qualidade, a tecnologia e a capacidade de inovação. Quando a empresa é socialmente responsável, atrai os consumidores e aumenta o potencial de vendas, gerando maiores lucros para os acionistas. Além disso, também é, hoje, um sinal de reputação corporativa e da marca» 52 .

Curial, assim, apegar-se à ética, e à moral, como palancas axiológicas que servem de baliza para o exercício das atividades de mercado,

51 Drucker, Peter F.: Administração: Tarefas, Responsabilidades, Práticas. São Paulo, Pioneira, 1975, 369.

52 Dunn, Robert. Quer uma vantagem competitiva? Revista Exame, 669, ano 32, n. 18, p. $5,26 / 08 / 1998$. 
sem que os agentes do negócio priorizem, com insanidade e insensatez, a busca pelo lucro contínuo a todo custo, e de toda forma.

A transmutação na atitude comportamental dos agentes de mercado levou às entidades empresariais ao desenvolvimento de práticas congêneres com o desenvolvimento da cidadania corporativa, as quais estão intrinsecamente relacionadas com o envolvimento social, o dever cívico e o comportamento solidário de homens sociais e fraternos.

É desta forma que a ação de responsabilidade social das empresas não totaliza uma ação individual, mas perfaz um exercício corporativo, que congrega o movimento-ação de todos, em prol da cidadania, da dignidade e do meio ambiente. Esta ideia de movimento ação não sepulta a necessidade, por vezes, de omissão positiva, no sentido de evitar-se toda e qualquer prática que possa afetar negativamente a sociedade, a pessoa, e o meio ambiente natural.

A singularidade que permeia a responsabilidade social está na alma, por assim dizer, da cooperatividade, revelando-se congênita do Cooperativismo, que tem no indivíduo, e na sua condição de existência digna, o início e o fim de todos os seus propósitos. "El hombre es el eje en torno al cual gira la concepción de la cooperativa como sociedad y como empresa. ${ }^{53}$

Desde as experiências cooperativas mais remotas, que precederam a constituição da sociedade dos Probos Pioneiros de Rochdale, em Manchester, no ano de 1844, a cooperação revela-se como um conjunto de condutas humanas inter-relacionadas, que apreciam o «valor de la reciprocidad de esas conductas, orientadas hacia formas de proceder de otros sujetos. Las acciones de unos sujetos están especialmente dirigidas a obtener determinadas respuestas de otros. Por ello podemos afirmar que en la Cooperación se da la existencia de relaciones sociales colectivas entre individuos y grupos dispuestas con un cierto orden de permanencia; organizadas y estructuradas hacia una acción común» ${ }^{54}$, que debe ter como objetivo o bem de todos.

A própria identidade cooperativa deixa patente que a sociedade cooperativa possui um aspecto híbrido, que a permite constitur-se como um instrumento útil tanto para o desenvolvimento econômico, como para o bem-estar social. Deve-se estar atento ao fato de que se a cooperativa fracassa como empresa, sua aptidão, e essência, como entidade promotora do desenvolvimento social e humano se esvai.

53 Salinas Ramos, F.: Notas para bucear en la identidad cooperativa. In Revista de Estudios Cooperativos. 61, 1995, p. 157.

54 Llombart Bosch, D.: Aproximación a la sociología de la cooperación. In Revista de Estudios Cooperativos. 77, Madrid: Asociación de Estudios Cooperativos, 1985, p. 80. 
Sim, é claro e indiscutível que a sociedade cooperativa reveste-se da natureza de ferramenta para alavancar o exercício econômico, mas este propósito encontra alicerce no fim maior do Cooperativismo, que é viabilizar a emancipação do sujeito e da sociedade. À luz da inspiração axio-principiológica dos estatutos da Sociedade dos Probos Pioneiros de Rochdale, e convergente com o sentido supremo da identidade cooperativa declarada pela Aliança Cooperativa Internacional, o homem é o início e o fim do Cooperativismo.

Esta é a ética da empresa cooperativa...

Ressalta-se, deste modo, que a conotação ética necessária ao mundo dos negócios apenas logrará solidez quando os empresários, e os demais agentes do mercado, compreenderem que a ética não institui normas delimitadoras da liberdade, mas propicia práticas que potencializam a realização das pessoas.

É justamente a partir do resgate da importância das pessoas, do valor do humano e do meio ambiente natural, que as organizações empresariais suplantarão toda e qualquer dificuldade para a perenização rentável de seus negócios. Isto, é certo e indubitável, perfaz o perfil atitudinal de uma sociedade cooperativa, que nasce para celebrar atividades de mercado, associando seu exercício às práticas sociais, humanas e ambientais.

A responsabilidade social é, em todos os sentidos, a causa e o efeito do Cooperativismo...

Indiferente à análise do modelo político ou da concepção econômica de cada país, as cooperativas estão disseminadas por todo o mundo, integrando culturas e sistemas que resguardem mesmo a mínima conjuntura populacional, que queira, sim, estimular um processo de reordenação econômica. Ocorre que este querer é derivativo de um querer maior, que perpassa pela transformação completa da pessoa humana.

Portanto, afirmar que a responsabilidade social é causa e efeito do Cooperativismo, é reconhecer a universalidade dos valores e princípios que norteiam a ação cooperativa, determinando que o Cooperativismo encontra-se apto para responder as necessidades humanas, seja quando for, e esteja a pessoa onde se encontrar. E esta universalidade é a grande riqueza do Cooperativismo, que nasceu no seio das multidões para sustentar a materialização dos infindáveis anseios de justiça social, pois a cooperatividade visa o bem das pessoas, da sociedae, do todo.

Conclui-se, assim, enaltecendo que a sociedade cooperativa é um modelo de entidade que desenvolve atividades de mercado, para a transformação de condições econômicas, o que faz, fortalecendo sua 
capacidade para ordenar a vida social, transformar os indivíduos e proteger o meio ambiente natural.

Este arquétipo não decorre da integração do conceito, dos valores e princípios cooperativos no corpo dos estatutos, ou no texto dos regimentos institucionais, mas resulta da maneira pela qual os elementos da indentidade são multiplicados através do exercício econômico da entidade organizada.

Com isto, será possível compreender-se que a sociedade cooperativa é, na sua essência identitária, uma entidade que possui a faculdade de moralizar o mundo produtivo, através de sua «alma» solidária, e da atitude fraterna de seus membros. Cumprindo com aquilo que lhe é causa e efeito, o Cooperativismo tento contribuirá para a redenção do socialis et adminicula hominum, como oportunizará o estabelecimento de um processo de equilíbrio social e de harmonização relacional. Esta prática de moralização, já provou-se, pode ser incrementada além das fronteiras das cooperativas, através de uma efetiva interação do Cooperativismos, com o entorno da sociedade organizda, especialmente através de um relacionamento direto, pedagógico e envolvente, com escolas, famílias e professores.

\section{Referências}

AbAd Colas, G.: La empresa cooperativa. Zaragoza, Centro Nacional de Educación Cooperativa, 1977.

ACl, Declaración de la Alianza Cooperativa Internacional sobre la Identidad Cooperativa aprobada en Manchester. Vitoria-Gasteiz, Consejo Superior de Cooperativas de Euskadi, 1996

Aguado, Javier Fernández. Ética y rentabilidad en la empresa. In Heredia, Pablo. J. B. (Coord.): Ética y actividad empresarial. Madrid, Minerva Ediciones, 2004.

AguilLAR, Fernando Herren: Direito econômico: do direito nacional ao direito supranacional. 2ed. São Paulo, Atlas, 2009.

Aranzadi Telleria, D.: Credibilidad del cooperativismo. in Anuario de Estudios Cooperativos. 1999. Bilbao, Universidad de Deusto, 1999.

ArizmendiarRieta, José Maria: Pensamientos. Caja laboral Popular, Estella, 1983.

BENEVIDES PINHO, D.: Evolución del pensamiento cooperativista. Buenos Aires, Intercoop Editora Cooperativa Limitada, 1987.

Brasil, Constituição da República. 1988. Disponível em: http://www.planalto. gov.br Acesso em 12 out. 2020.

BrasIL, Constituição Federal. Vade mecum 2014. São Paulo: RT. 2014.

BIRCHALL, J.: Discurso de apertura. in Revista de la Cooperación Internacional. 28,1, ACl, 1995. 
BItTAR, Eduardo C. B.: Ética, educação, cidadania e direitos humanos: Estudos filosóficos entre cosmopolitismo e responsabilidade social. São Paulo. Manole, 2004.

BSD, Responsabilidade social empresarial. Disponível em http://www.inmetro. gov.br/multiplicadores acesso em 17 set 2020.

CARDoso, Alexandre J. G.: A responsabilidade social nos negócios: um conceito em construção. In Ashley, Patrícia Almeida (org.). Ética e responsabilidade social nos negócios. São Paulo, Saraiva, 2002.

ConfederaÇão Nacional Da Indústria, Responsabilidade social empresarial. CNI, Brasília, 2006.

Da Silva, José Afonso. Curso de direito constitucional positivo. 26 ed., São Paulo, Malheiros, 2006.

DunN, Robert. Quer uma vantagem competitiva? Revista Exame, 669, ano 32, n. 18, p. $5,26 / 08 / 1998$.

Drucker, Peter F.: Administração: Tarefas, Responsabilidades, Práticas. São Paulo, Pioneira, 1975.

ESPASA, Diccionario de la Lengua Española. Madrid: Espasa Calpe, 2001.

Grau, Eros R.: A ordem econômica na Constituição de 1988. 3 ed. São Paulo, Malheiros, 1997.

Instituto Ethos, O que é SER? 2011. Disponível em www.ethos.org.br/ EthoWeb/pt/29/o_que_e_rse Acesso em 14 set 2020.

JúNIOR, Tércio Sampaio Ferraz: Livre-iniciativa. Propaganda de alimentos e competência da anvisa. In Gaban, Eduardo Molan e Domingues, Juliana Oliveira: Estudos de direito econômico e economia da concorrência. Curitiba: Juruá, 2009.

LADILAW, A. F.: Las cooperativas en el año 2000. México D. F., ACl-Confederación Mejicana de Cajas Populares, 1981.

LASSERRE, G.: El hombre cooperativo. Buenos Aires, Intercoop Editora Cooperativa Limitada, 1980.

LLOMBART BosCh, D.: Aproximación a la sociología de la cooperación. In Revista de Estudios Cooperativos. 77, Madrid: Asociación de Estudios Cooperativos, 1985, p. 80.

LUNDBORG, Louis. Public relations in the local community. 1950.

MIRANDA, José Eduardo de: De la crisis de identidad al rescate de la génesis del cooperativismo. Madrid, Dykinson, 2012.

MIRANDA, José Eduardo. Filosofía cooperativa: análisis del proceso de conformación del cooperativismo. Curitiba, Juruá, 2017.

Miranda, José Eduardo et al. Meio Ambiente e Cooperação: os valores cooperativos como pressuposto de sustentabilidade. Boletín de la Asociación Internacional de Derecho Cooperativo. Bilbao: Universidad de Deusto, n. 44, 2010. p 17.

MORAES, Alexandre de: Constituição do Brasil interpretada e legislação constitucional. 5 ed. São Paulo, Atlas, 2005.

PINSKY, Jaime \& PINSKY, Carla Bassanezi (org). História da cidadania. 2.ed. São Paulo: Contexto, 2008. 
SACCHell, Roseana Cilião: A livre iniciativa e o princípio da função social nas atividades empresariais no contexto globalizado. In Revista da AJURIS. v. 40 —n. 129- Março 2013. Disponível em http://www.ajuris.org.br/OJS2/ index.php/REVAJURIS Acesso em 09 set 2020.

Salinas RAMOS, F.: Notas para bucear en la identidad cooperativa. In Revista de Estudios Cooperativos. 61, 1995.

SOLDEVILLA Y VILLAR, A. D. El movimiento cooperativista mundial: sus orígenes, desarrollo y problema actual. Valladolid: Talleres Gráficos Ceres, 1973.

SUOMELA, K.: Los valores básicos de las cooperativas de consumo. In Revista de la Cooperación Internacional. 24, 1, ACl, 1991, p. 11.

Vasquez, Adolfo Sánchez. Ética. 1990.

ZENISEK, Thomas J.: Corporate social responsability, a conceptualization based on organizational literature. Apud OLIVEIRA, José Arimatés de. Responsabilidade social em pequenas e médias empresas. In Revista de Administração de Empresas, 24 (4): 204, out./dez.1984. 


\section{Derechos de autor}

http://dec.revistas.deusto.es/

La revista Deusto Estudios Cooperativos es una revista de acceso abierto lo que significa que es de libre acceso en su integridad inmediatamente después de la publicación de cada número. Se permite su lectura, la búsqueda, descarga, distribución y reutilización legal en cualquier tipo de soporte sólo para fines no comerciales y según lo previsto por la ley; sin la previa autorización de la Editorial (Universidad de Deusto) o el autor, siempre que la obra original sea debidamente citada (número, año, páginas y DOI si procede) y cualquier cambio en el original esté claramente indicado.

\section{Copyright}

The Deusto Journal of Cooperative Studies is an Open Access journal which means that it is free for full and immediate access, reading, search, download, distribution, and lawful reuse in any medium only for non-commercial purposes, without prior permission from the Publisher or the author; provided the original work is properly cited and any changes to the original are clearly indicated. 